\title{
Comments on brazilian Halichondria Fleming (Halichondriidae, Halichondrida, Demospongiae), with the description of four new species from the São Sebastião Channel and its environs (Tropical Southwestern Atlantic)
}

\author{
Mariana de S. Carvalho ${ }^{1}$ \\ Eduardo Hajdu ${ }^{1}$
}

\begin{abstract}
Over 70 species of Halichondria Fleming, 1828 are known world-wide, but only five from the Brazilian Coast. Brazilian records have their status re-evaluated here, and four new species are described for the São Sebastião Channel area, in the Tropical Southwestern Atlantic, viz. H. cebimarensis sp. n., H. sulfurea sp. n., $H$. migottea sp. n. and H. tenebrica sp. n.

KEY WORDS. Porifera, Halichondria, taxonomy, Brazilian coast, Southwestern Atlantic, new species
\end{abstract}

Halichondria Fleming, 1828 is a genus which poses special challenges to the porifera taxonomist due to a shortage of conspicuous anatomical characters. Species may have one or more categories of oxeas, frequently hard to tell apart, distributed in a criss-crossed pattern, where spicular tracts are seldom visible. Such absence of a pattern is known as the halichondroid architecture.

There are nevertheless over 70 species described for the whole world, and the detailed study of these records has gained some momentum with the discovery of biologically active metabolites in some Halichondria (e.g. MUNRo et al. 1994). For the Brazilian coast, six species were cited previously (DE LAUBENFELS 1956; JOHNSON 1971; HECHTEL 1983; MURICY et al. 1991; LERNER 1996; MURICY \& Moraes 1998), viz. Halichondria ("Menanetia") sp.; Halichondria sp.; H. braziliensis Hechtel, 1983; H. panicea (Pallas, 1766); H. lutea Alcolado, 1984 and $H$. magniconulosa Hechtel, 1965. The status of these records will be discussed below. It is the purpose of this article to describe four new species found in the São Sebastião Channel area.

\section{MATERIAL AND METHODS}

Specimens were studied in situ whenever possible. The underwater photographs were taken by the senior author with a Nikonos V underwater camera and a close-up kit (close-up lens or extension tubes). Size classes for the range of possible spicule lengths were obtained by using the classic Sturges' algorithm $(1+3.3 \log \Delta$, where " $\Delta$ " is the range between largest and smallest lengths). They were collected with a diver's knife through scuba diving or wading at low tide. Preparations of

1) Departamento de Invertebrados, Museu Nacional, Universidade do Brasil. Quinta da Boa Vista, 20940-040 Rio de Janeiro, Rio de Janeiro, Brasil. E-mail: hajdu@acd.ufrj.br 
dissociated spicules and thick sections slides follow the usual procedures as described elsewhere (MOTHES-DE-MORAES 1985; HOOPER 1997) for study under light microscopy. Figure 1 shows the collecting localities in the São Sebastião area, and the latter's position with regard to the Southeastern Brazilian coastline and the Southwestern Atlantic.

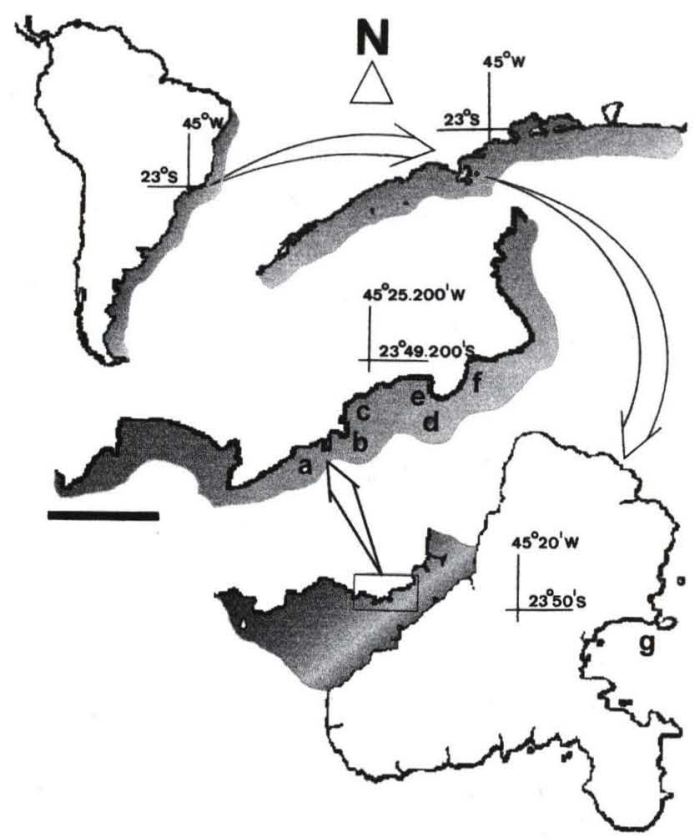

Fig. 1. Map showing South America, a section of the Southeastern Brazilian coastline, Ilha de São Sebastião; and, in detail, the continental face of São Sebastião Channel, with the collecting localities indicated. (a) Saco Grande, $23^{\circ} 49.715^{\prime} S-45^{\circ} 25.480^{\prime} \mathrm{W}$, next to Ponta do Baleeiro; (b) Ponta do Jarobá, $23^{\circ} 49.676$ 'S $-45^{\circ} 25.278^{\prime} W$; (c) Rocky coast between Praia does Cabelo

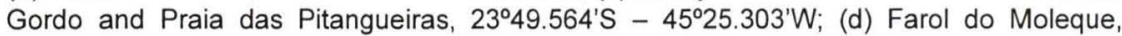

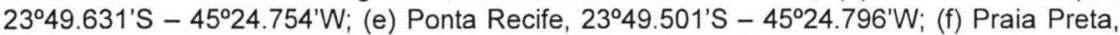
$23^{\circ} 49.247^{\prime} \mathrm{S}-45^{\circ} 24.435^{\prime} \mathrm{W}$; (g) Celada, $23^{\circ} 50.563^{\prime} \mathrm{S}-45^{\circ} 14.402^{\prime} \mathrm{W}$. Scale bar $=1 \mathrm{~km}$ (a-f), $5 \mathrm{~km}(\mathrm{~g})$.

Abbreviations used are: (BMNH) The Natural History Museum, London, U.K.; (CEBIMar/USP) Centro de Biologia Marinha, Universidade de São Paulo, São Sebastião, SP, Brazil; (MCNZ) Museu de Ciências Naturais, Fundação Zoobotânica do Rio Grande do Sul, Porto Alegre, RS, Brazil; (MNRJ) Museu Nacional, Universidade do Brasil, Rio de Janeiro, Brazil; (YPM) Yale Peabody Museum, New Haven, CT, U.S.A.; (UFRJPOR) Universidade do Brasil, Porifera Collection - also at Museu Nacional; (UESC) Universidade Estadual de Santa Cruz, Ilhéus, Bahia, Brazil; (UNICAMP) Universidade Estadual de Campinas, Campinas, São Paulo, Brazil; (USNM) National Museum of Natural History, Smithsonian Institution, Washington D.C., U.S.A.; (ZMA) Zoologisch Museum, Amsterdam, The Netherlands. 


\section{RESULTS}

\section{Halichondrida Vosmaer, 1885 \\ Halichondriidae Vosmaer, 1887}

\section{Halichondria Fleming, 1828}

Diagnosis. Massive-amorphous; ectosomal skeleton with thin, tangential peel, clearly detachable, composed of single, or vague bundles of smaller oxeote spicules, supported by choanosomal columns of oxeas traversing subdermal spaces; choanosome has the appearance of a disordered loose reticulation ("halichondroid" structure), and spicule tracts are poorly defined, directionless; oxeote spicules of intermediate to relatively small size, sometimes modified to quasistylote or even true styles; ectosomal structure may be secondarily lost; microscleres absent or may include raphides occurring singly or in bundles (trichodragmata) in "Raspaigella"; larvae are incubated and tufted-ciliate (HOOPER 1997). Type species: Spongia panicea Pallas, 1766).

\section{Halichondria cebimarensis sp. $\mathbf{n}$.}

Figs 2, 5, 9a-b, 10a-b, 14; Tab. I

Holotype: MNRJ 2030, Ponta do Jarobá, Canal de São Sebastião, SP, 2 m depth, E. Hajdu leg., 28/I/1999. Schyzotypes from holotype: BMNH 1999.5.12.1, ZMA 13629.

Paratypes: MNRJ 269, Ponta Recife, Canal de São Sebastião, São Sebastião, SP, 2 m depth, E. Hajdu leg., 22/I/1996; MNRJ 372, Farol do Moleque, Canal de São Sebastião, São Sebastião, SP, E. Hajdu leg., 29/I/1996; MNRJ 374, Ponta do Jarobá, Canal de São Sebastião, São Sebastião, SP, 2 m depth, E. Hajdu leg., 29/I/1996; MNRJ 709, Praia Preta, Canal de São Sebastião, São Sebastião, SP, 1.5 m depth, E. Hajdu leg., 3/I/1996; MNRJ 1301, 1328, Praia Preta, Canal de São Sebastião, São Sebastião, SP, 1-2 m depth, E. Hajdu \& Colls leg., 22/XII/1997; MNRJ 1943, 1944, Praia Preta, Canal de São Sebastião, São Sebastião, SP, ca. 2 m depth, E. Hajdu \& Colls leg., 27/XI/1998.

Comparative material. Halichondria corrugata Diaz et al., 1993 - USNM 23566 (holotype), Gulf Coast of Florida, $3 \mathrm{~m}$ depth. Halichondria panicea (Pallas, 1766) - MNRJ 1150, 1155, Chenal de l'Ile Vert (Roscoff, France), det. EH, C. Lévi \& R.W.M. van Soest

Diagnosis. Halichondria cebimarensis $\mathbf{s p}$. $\mathbf{n}$. is set apart from other Tropical Western Atlantic Halichondria species by its turquoise colour alive, and oxeas in a single category mostly larger than $300 \mu \mathrm{m}$ in length and $10 \mu \mathrm{m}$ thick, and by the absence of grooves on oscular chimneys.

Description. Many specimens were seen in the field. The largest one, collected for screening for natural products was about $15 \mathrm{~cm}$ long and wide, and about $7 \mathrm{~cm}$ high. The holotype was $8 \mathrm{~cm}$ long, $5.5 \mathrm{~cm}$ wide and $2.5 \mathrm{~cm}$ high (Fig. 5). Shape is often massive, cushion-like, only seldom incrusting (MNRJ 269). Shape is very often irregular, with no clear pattern of projections (e.g. oscular chimneys), 


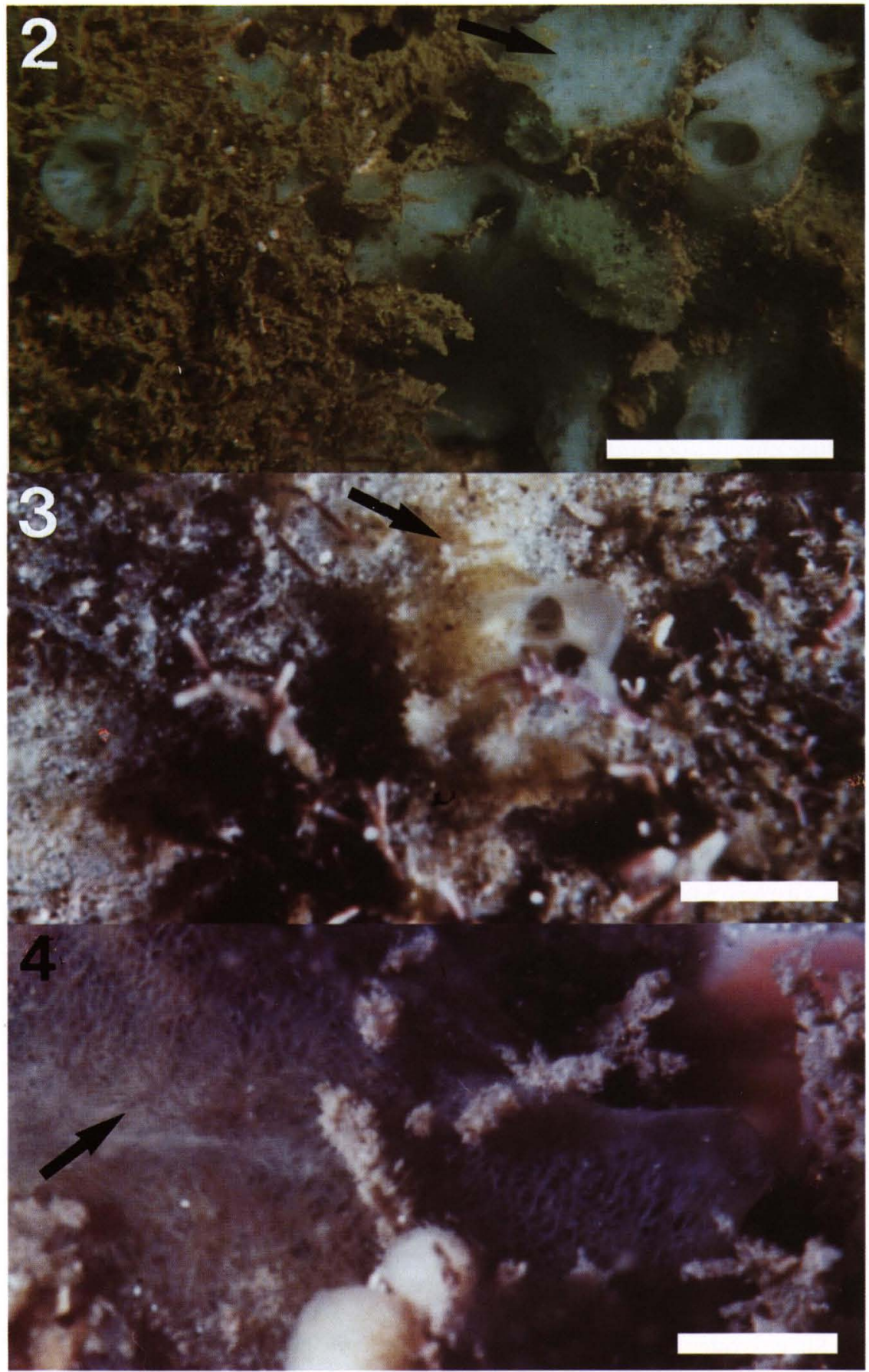

Revta bras. Zool. 18 (Supl. 1): 161 - 180, 2001 
which is partly explained by the species' common association to varied organisms, as well as to the possible inclusion of abundant large-sized (over $1 \mathrm{~cm}$ in diameter) debris (MNRJ 372; MNRJ 2030, Fig. 2). Volcaniform projections, 1-3 cm high, topped by oscula are conspicuous in a single specimen (MNRJ 374). Oscula (0.5 $\mathrm{mm}$ across) are often spread randomly. Consistency is firm, but easily torn. Texture is mostly rough. The surface appears reticulated to the naked eye, and is easily detached. Live colour is typically a light-green, often bluish (turquoise, Fig. 2).

Skeleton. The ectosomal skeleton (Fig. 9a) comprises a confused (para) tangential reticulation of oxeas, where primary and secondary tracts are only barely discernible. The choanosomal network (Fig. 9b) is confused, halichondroid, crossed by large acquiferous channels (up to $3 \mathrm{~mm}$ across).

Spicules (Figs 10a-b, 14, Tab. I). Oxeas, fusiform, slightly curved, rarely straight, mostly tapering gradually but sometimes slightly hastate, malformations very rare. Dimensions: 164.9 to $630.5 \mu \mathrm{m}$ in length and 3.6 to $18 \mu \mathrm{m}$ thick.

Ecology. The species has been found under small overhangs, or associated to algae (e.g. Sargassum) in photophilous habitats. Among the most commonly found associates are ophiuroids (two species, 136 specimens in the largest Halichondria - this sponge has been collected for marine natural products' research), tubeworms, ectoprocts and calcareous algae.

Table I. Halichondria cebimarensis sp. $\mathbf{n}$. Comparative micrometric data for the holotype and paratypes. $H$. corrugata. Micrometric data for the holotype. Measures are given as smallest length - mean length - largest length/ smallest width - mean width - largest width, in micrometers. $\mathrm{N}=100$ for length measures and $\mathrm{N}=20$ for width measures unless stated otherwise.

\begin{tabular}{|c|c|}
\hline Specimens & Oxeas-1 \\
\hline \multicolumn{2}{|l|}{ Halichondria cebimarensis sp. $\mathrm{n}$. } \\
\hline Holotype MNRJ 2030 - total & $(110-260) 330-461.2-620 / 5-9.1-13.7$ \\
\hline Holotype MNRJ 2030 - surface & $180-437.3-580(\mathrm{~N}=50) / 7.2-10.5-14.4$ \\
\hline Holotype MNRJ 2030 - base & $370-461.6-610(N=50) / 6-10.1-16.8$ \\
\hline Paratype MNRJ 269 & $329-447.7-582 / 3.6-8.8-16.8$ \\
\hline Paratype MNRJ 372 & $310-453.2-612 / 4.8-10.4-18$ \\
\hline Paratype MNRJ 374 & $281-436.1-592 / 3.6-8.6-14.4$ \\
\hline Paratype MNRJ 709 & (165) 296-448.4-597/4.8-11.0-18 \\
\hline Paratype MNRJ 1301 & (175) $315-488.3-631 / 3.6-10.9-16.8$ \\
\hline Paratype MNRJ 1328 & $320-466.4-621 / 3.6-9.7-15.6$ \\
\hline Paratype MNRJ 1943 & $260-433.6-580 / 3.7-8.3-13.7$ \\
\hline Paratype MNRJ 1944 & $310-431.3-560 / 3.7-2.1-13.7$ \\
\hline \multicolumn{2}{|l|}{ Halichondria corrugata } \\
\hline Original description & $130-370-520 / 5-2-12$ \\
\hline Holotype here remeasured & $155-406.1-572 / 4-8.6-13$ \\
\hline
\end{tabular}

Fig. 2-4. 2. Halichondria cebimarensis sp. n., holotype (MNRJ 2030). Specimen seen alive at Ponta do Jarobá. Note its turquoise colour. The new species is overgrown by algae, and by the green sponge, Amphimedon viridis Duchassaing \& Michelotti, 1864 (arrow). Scale bar = $2 \mathrm{~cm}$. (3) Halichondria sulfurea sp. n., paratype (MNRJ 478). Specimen seen alive between Praia do Cabelo Gordo and Ponta do Jarobá. Scale bar $=2 \mathrm{~cm}$. (4) Halichondria tenebrica sp. n., holotype (MNRJ 521). Specimen seen alive between Praia do Cabelo Gordo and Ponta do Jarobá. Scale bar $=2 \mathrm{~cm}$. 
Etymology. The species is named after the Centro de Biologia Marinha (CEBIMar), of the University of São Paulo, at São Sebastião, both a historical monument of brazilian marine biology in the past half century, and a sure partner in developments to come. All the fieldwork conducted in the São Sebastião Channel area by the senior author in the last 10 years has depended heavily on the lab's facilities.
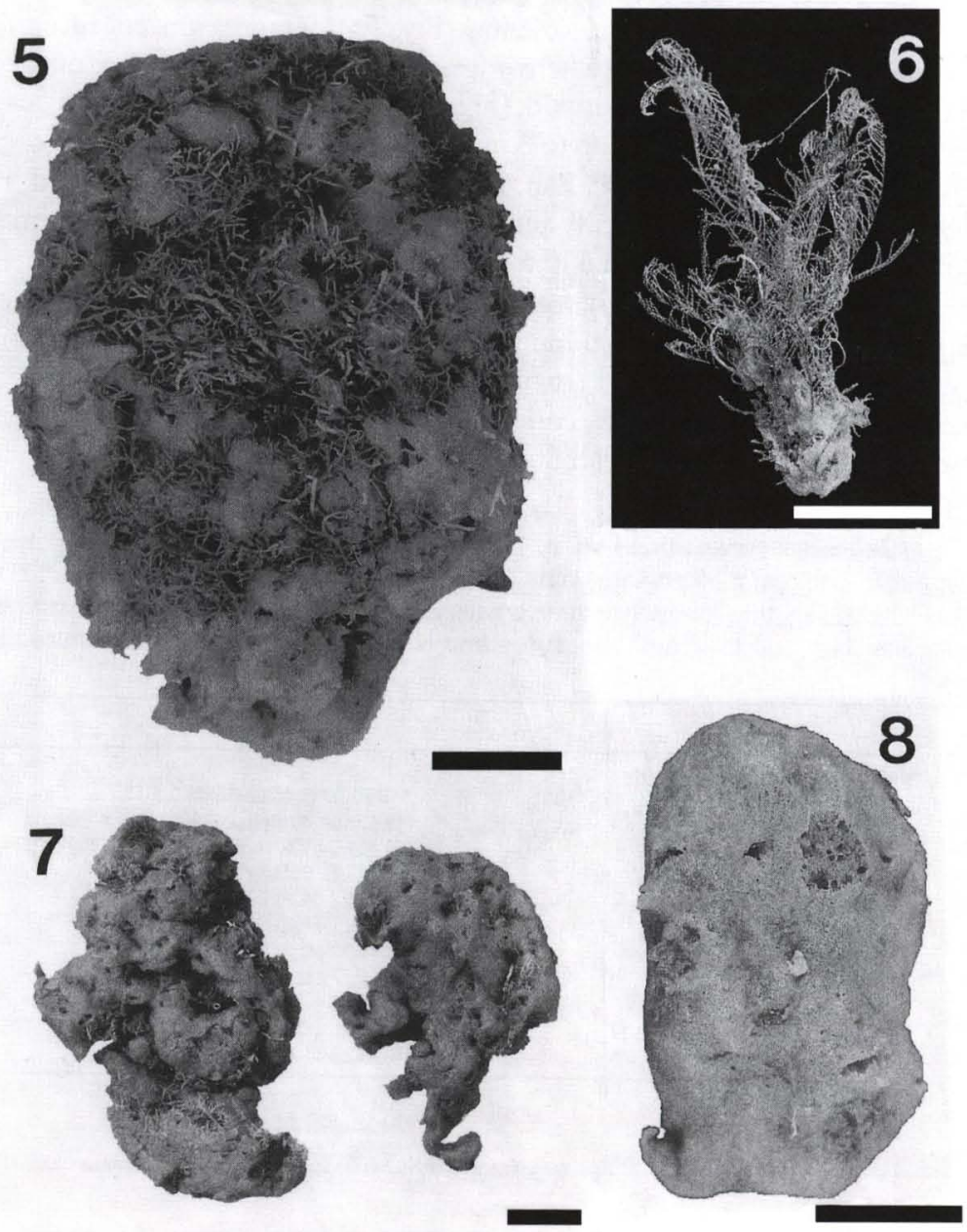

Figs 5-8. (5) Halichondria cebimarensis sp. n., holotype (MNRJ 2030). Specimen in its current state of preservation, after fixation in ethanol. (6) Halichondria migottea sp. n., holotype (MNRJ 1333 ) in its current state of preservation, after fixation in ethanol. Note association to the hidroid Dentitheca sp. (7) Halichondria sulfurea sp. n., holotype (MNRJ 1034) in its current state of preservation, after fixation in ethanol. (8) Halichondria tenebrica sp. n., holotype (MNRJ 521) in its current state of preservation, after fixation in ethanol. Scale bars $=1 \mathrm{~cm}$. 
Remarks. Halichondria cebimarensis sp. $\mathbf{n}$. is distinguished from typical European $H$. panicea by its only rare possession of small oxeas (ca. $100 \mu \mathrm{m}$ long), and by the considerably larger mean length of its oxeas $(433-488 \mu \mathrm{m}$ vs. ca. $300 \mu \mathrm{m})$. An interpretation on the status of records of $H$. panicea for the Brazilian Coast is furnished in the Discussion.
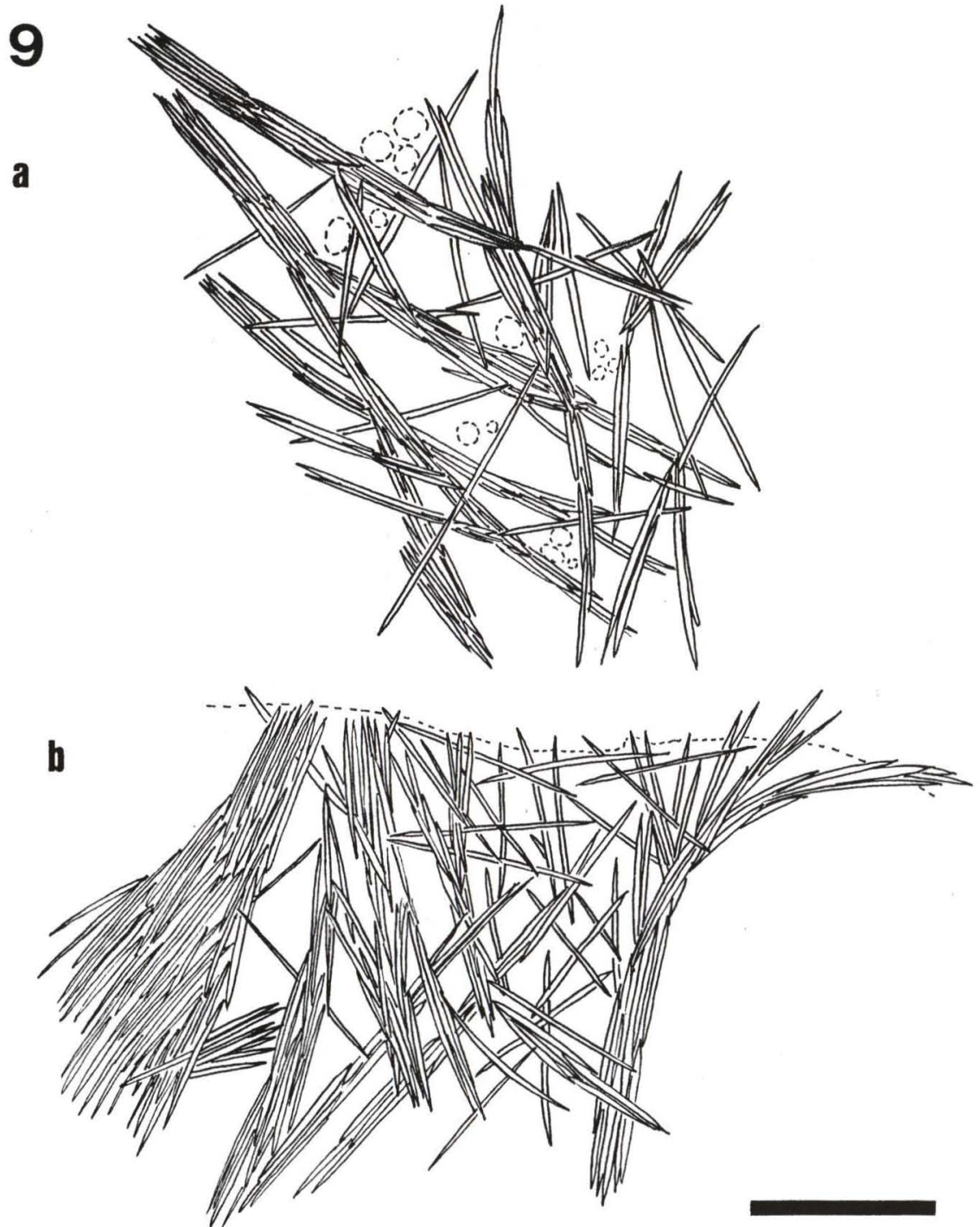

Fig. 9. Halichondria cebimarensis sp. n. (a) Ectosomal skeleton, pores are indicated as dashed rounded areas; (b) choanosomal skeleton. Scale bar $=400 \mu \mathrm{m}$. 

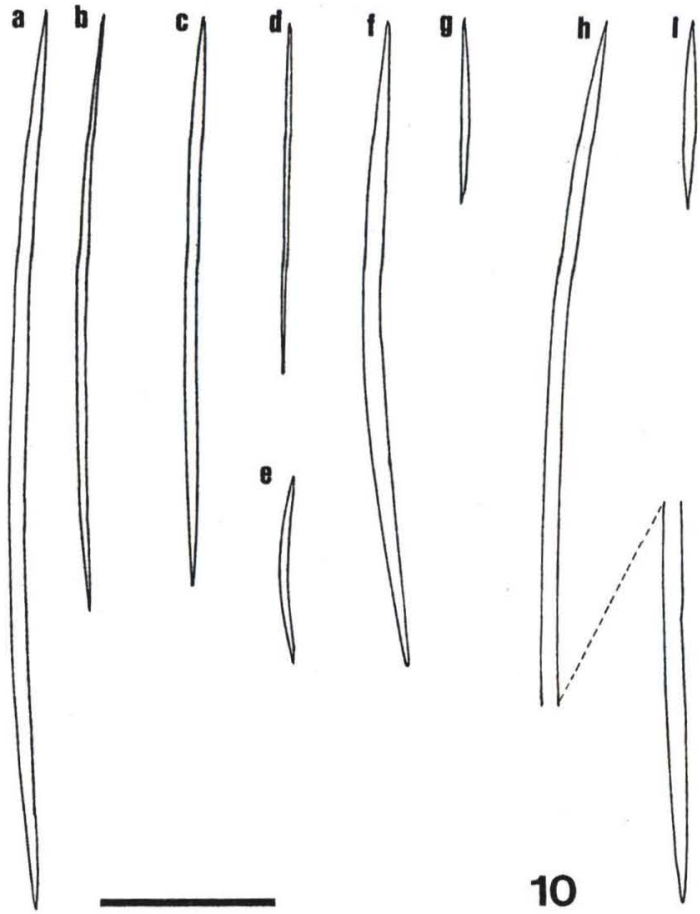

Fig. 10. (a-b) Halichondria cebimarensis sp. n.: (a) larger and (b) smaller oxeas; (c-e) Halichondria migottea sp. n.: (c) oxeas I, (d) oxeas II, (e) oxeas III; (f-g) Halichondria sulfurea sp. n.: (f) larger and (g) smaller oxeas; (h-i) Halichondria tenebrica sp. n.: (h) larger and (i) smaller oxeas. Scale bar $=100 \mu \mathrm{m}$.

The new species approaches $H$. corrugata very closely. Overall sponge morphology and spicule dimensions are partly very similar. Both species differ though in some traits: viz. presence of small oxeas frequent (ca. $150 \mu \mathrm{m}$ long), presence of grooves on oscular chimneys and occurrence of greenish-brown and pink specimens in H. corrugata. These traits coupled to both species' allopatric occurrences are considered solid enough to warrant their recognition as distinct, possibly sister-species.

Oxeas under $200 \mu \mathrm{m}$ in length were found in the holotype of $H$. cebimarensis sp. n., $2030(\mathrm{~N}=3 / 200)$, and in two paratypes, $709(\mathrm{~N}=4 / 100)$ and $1301(\mathrm{~N}=$ $2 / 100$ ). The small oxeas in the paratypes could be allochtonous, possibly of haplosclerid origin (slightly 'cigar-shaped'), but those found in the holotype appear to be proper, although very rare.

\section{Halichondria migottea sp. $\mathbf{n}$.}

Figs 6, 10c-e, 11a-b; 14; Tab. II

Holotype. MNRJ 1333, Saco Grande, next to Ponta do Baleeiro, Canal de São Sebastião, São Sebastião, SP, 1.5-2 m depth, A.E. Migotto leg., 3/IX/1996. 
Diagnosis. H. migottea sp. $\mathbf{n}$. is the only Tropical Western species of Halichondria with greyish-brown live colour, and three size categories of oxeas with mean lengths around 100, 200 and $300 \mu \mathrm{m}$.

Description. Thickly encrusting, compressible, with an irregular surface. The holotype is $15 \times 6 \times 4 \mathrm{~mm}$ (length, width, thickness, Fig. 6). Live colour is greyish-brown, turning yellowish-white in spirit.

Skeleton. The ectosomal skeleton (Fig. 11a) is mostly confused, but a few loose, sinuous tangential tracts (2-3 spicules across) are visible. The choanosomal architecture (Fig. 11b) is essentially halichondroid. Round embryos (250-290 $\mu \mathrm{m}$ in diameter) are present.
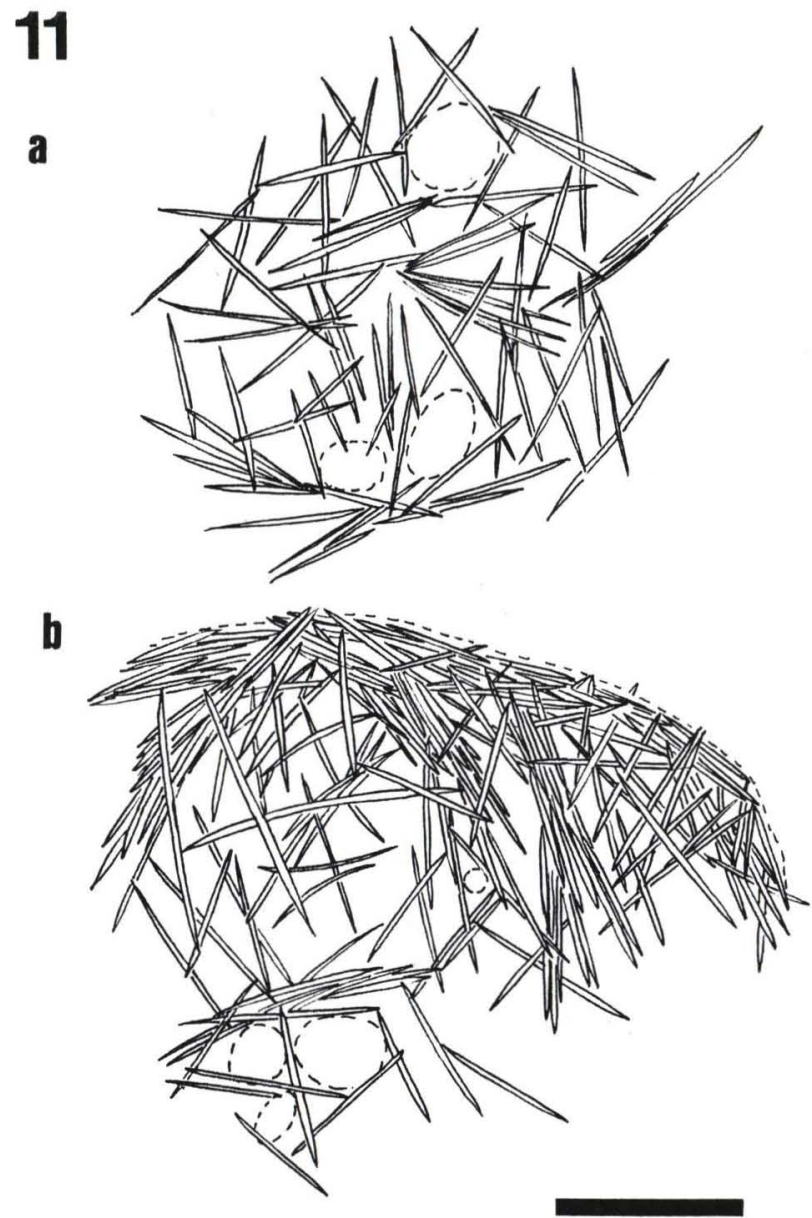

Fig. 11. Halichondria migottea sp. n. (a) Ectosomal skeleton, pores are indicated as dashed rounded areas; (b) choanosomal skeleton, acquiferous canals are indicated as dashed rounded areas. Scale bar $=200 \mu \mathrm{m}$. 
Spicules (Figs 10c-e, 15, Tab. II). Oxeas I - fusiform, mostly slightly curved, seldom straight, tapering gradually. Oxeas II - slender, tapering gradually. Oxeas III - more robust than -II, fusiform, slightly curved, tapering gradually.

Table II. Halichondria migottea sp. n. Micrometric data for the holotype. H. sulfurea sp. n. Micrometric data for the holotype and paratypes. H. magniconulosa. Micrometric data for the holotype. $\mathrm{H}$. tenebrica sp. $\mathrm{n}$. Micrometric data for the holotype and paratype. Measures are given as smallest length - mean length - largest length/ smallest width - mean width - largest width, in micrometers. $\mathrm{N}=100$ for length measures and $\mathrm{N}=20$ for width measures.

\begin{tabular}{|c|c|c|c|}
\hline Specimens & Oxeas-I & Oxeas-II & Oxeas-III \\
\hline $\begin{array}{l}\text { Halichondria migottea sp. n. } \\
\text { Holotype MNRJ }\end{array}$ & $262-329.8-417 / 4.8-7.1-9.6$ & $194-214.5-233 / 2.4-2.8-3.6$ & $102-112.8-121 / 3.6-4.9-6$ \\
\hline $\begin{array}{l}\text { Halichondria sulfurea sp. } \mathrm{n} \text {. } \\
\text { Holotype MNRJ } 1034 \\
\text { Paratype MNRJ } 342 \\
\text { Paratype MNRJ } 478 \\
\text { Paratype MNRJ } 506 \\
\text { MNRJ } 508\end{array}$ & $\begin{array}{l}107-276.9-446 / 4.8-8.7-12 \\
100-\underline{312.2}-460 / 3.7-8.4-12.5 \\
97-\underline{222.1}-349 / 2.4-5.8-10.8 \\
101-305.7-388 / 4.8-8.1-12 \\
210-\underline{341.5}-582 / 2.5-7.7-11.2\end{array}$ & & \\
\hline $\begin{array}{l}\text { Halichondria magniconulosa } \\
\text { Original description } \\
\text { Sensu DIAZ et al. (1993) } \\
\text { Holotype here remeasured }\end{array}$ & $\begin{array}{l}108-369 / 3-7 \\
200-500 / 5-10 \\
87-234.4-349 / 1.2-4.7-8.4\end{array}$ & $\begin{array}{l}100-250 / 2-5 \\
\text { Not found }\end{array}$ & $\begin{array}{l}40-110 / 2-4 \\
\text { Not found }\end{array}$ \\
\hline $\begin{array}{l}\text { Halichondria tenebrica sp. n. } \\
\text { Holotype MNRJ } 521 \\
\text { Paratype MNRJ } 1316\end{array}$ & $\begin{array}{l}116-368.0-650 / 4.8-10.2-16.8 \\
126-351.0-708 / 5.0-11.4-17.5\end{array}$ & & \\
\hline
\end{tabular}

Ecology. The only collected specimen is epibiontic over the hydroid Dentitheca, and was collected at 1.5-2 $\mathrm{m}$ depth.

Etymology. The species is named after Prof. Dr. Alvaro Esteves Migotto of the Centro de Biologia Marinha, of the University of São Paulo, at São Sebastião. The name is dedicated to both the fact that he is the collector of the species, as well as to his commitment to the marine biology of the São Sebastião Channel area.

Remarks. There are another two shallow-water Halichondria from the Tropical Western Atlantic with three categories of oxeas mentioned. One of them, H. magniconulosa (cf. DiAz et al. 1993), has a tendency to exhibit size frequency peaks, but no true category is found, as intermediate sizes are plentiful. Additionally, the restudy of its holotype revealed only two such peaks, as opposed to three, clearly separated ones in the new species described here (Fig. 14). Halichondria sp. was described by JOHNSON (1971) from the NE Brazilian coast. Her dry specimen was dull-white, possessing oxeas which, in general, are much larger than those found in H. migottea sp. n. (325-875 vs. 102-417 $\mu \mathrm{m}$ in length, respectively).

\section{Halichondria sulfurea sp. $\mathbf{n}$.}

Figs 3, 7, 10f-g, 12a-b, 15; Tab. II

Holotype. MNRJ 1034, Rocky-coast between Praia do Cabelo Gordo and Praia das Pitangueiras, Canal de São Sebastião, São Sebastião, SP, 0.5-1 m depth, R.G.S. Berlinck leg., 27/II/1995.

Schizotypes. BMNH 1999.5.12.2, ZMA 13630. 
Paratypes. MNRJ 342, Celada, Baía de Castelhanos, 5-16 m depth, E. Hajdu \& G. Muricy leg., 25/I/1996; MNRJ 478, Rocky-coast between Praia do Cabelo Gordo and Ponta do Jarobá, Canal de São Sebastião, São Sebastião, SP, 0.5-1 m depth, E. Hajdu leg., 16/VI/1997; MNRJ 506, small beach at the Southern end of Praia do Araçá, Canal de São Sebastião, São Sebastião, SP, intertidal, E. Hajdu leg., 23/VI/1997.

Additional material. MNRJ 508, small beach at the Southern end of Praia do Araçá, intertidal, Canal de São Sebastião, São Sebastião, SP, E. Hajduleg., 23/VI/1997.
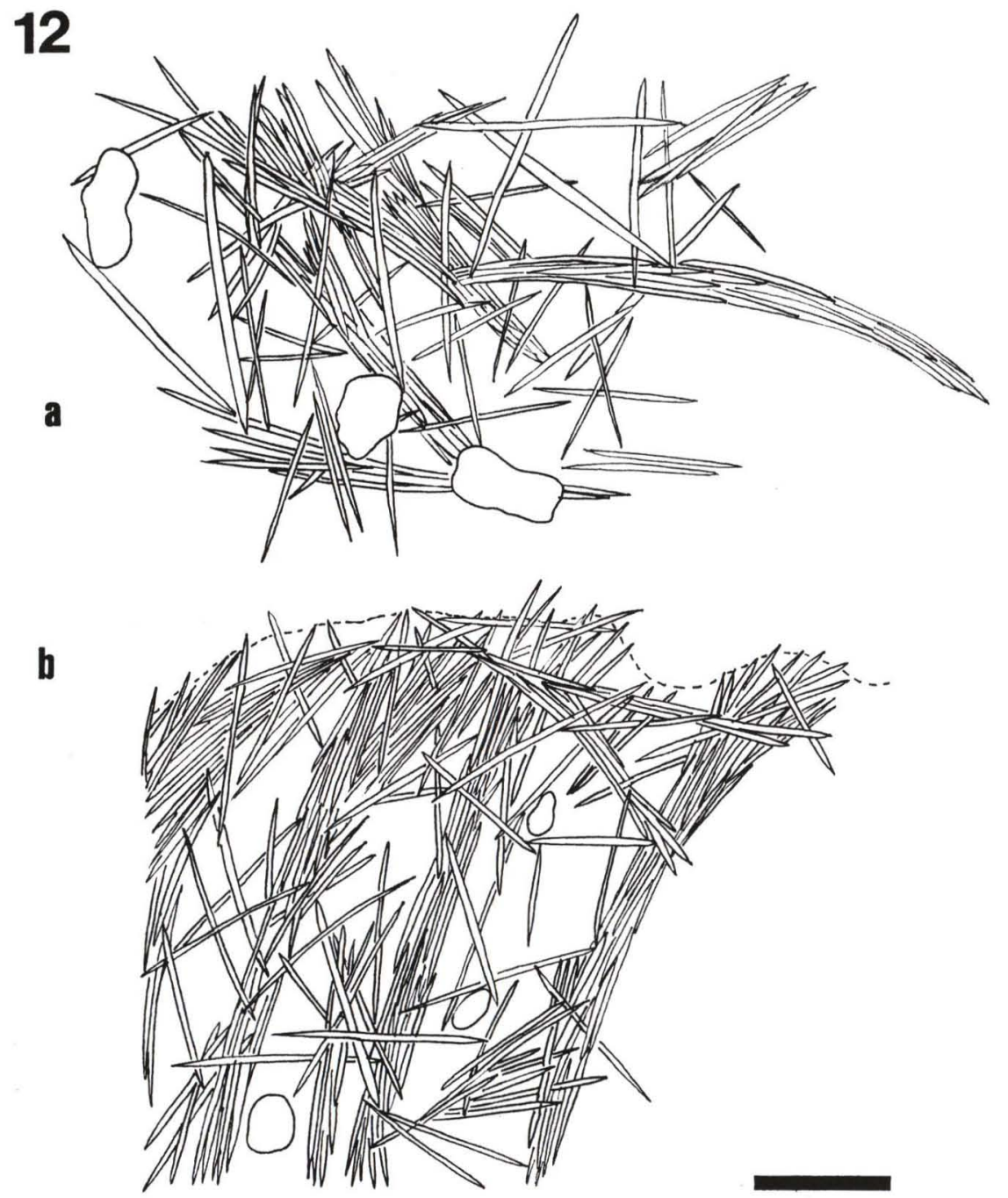

Fig. 12. Halichondria sulfurea sp. n. (a) Ectosomal skeleton, sand grains are indicated as irregular rounded outlines; (b) choanosomal skeleton, sand grains are indicated as irregular rounded outlines. Scale bar $=200 \mu \mathrm{m}$. 
Comparative material. Halichondria magniconulosa Hechtel, 1965- YPM 5039 (holotype), Rasta's wreck, on wood pilings, Port Royal, Jamaica. UFRJPOR 4021 (Tamandaré, Pernambuco State, Brazil; cf. Muricy \& Moraes 1998).

Diagnosis. Halichondria sulfurea sp. $\mathbf{n}$. is set apart from other Tropical Western Atlantic Halichondria species by its yellow colour; and oxeas in a single diverse category ranging from 97 to $460(582$ ?) $\mu \mathrm{m}$ in length, where no tendency for the occurrence of size category peaks in their size frequency distribution is observed. Oxeas are 2.4-12.5 $\mu \mathrm{m}$ thick.

Description. The holotype comprises two fragments: the largest one is $59 \mathrm{x}$ $37 \times 12 \mathrm{~mm}$ (length, width, height), the smallest $49 \times 32 \times 10 \mathrm{~mm}$ (Figs 3, 7). Cushion-shaped, compressible, irregular surface with small lobate projections (0.5-1 cm high). Oscules are spread over the surface (ca. $1 \mathrm{~mm}$ in diameter). Live colour is yellow, turning beige in alcohol.

Skeleton. The ectosomal skeleton of the holotype is composed by primary tangential tracts (2-10 spicules across) to which abundant spicules strewn at random are added. Some sediment grains are present (Fig. 12a). Primary tangential tracts are not discernible in specimen 342 . The choanosome is cavernous. The choanosomal network is made by loose tracts running to the surface, where many perpendicular brushes are seen laying side by side. Scattered spicules are very common everywhere (Fig. 12b).

Spicules (Figs 10f-g, 15, Tab. II). Oxeas smooth, slightly curved (seldom straight, often in MNRJ 342), mostly slightly fusiform, often tapering abruptly. Uncommon styloid modifications in MNRJ 342. Dimensions. 97-460(582?) $\mu \mathrm{m}$ in length and 2.4-12.5 $\mu \mathrm{m}$ thick.

Ecology. The holotype is associated to calcareous algae. MNRJ 342 is associated to barnacles and ophiuroids. Specimens MNRJ 506 e 508 were collected in an intertidal tunnel, where water currents can be strong.

Etymology. The species is named sulfurea (from sulfureus - latin for sulfur-yellow), due to its yellow live colour.

Remarks. The new species approaches H. magniconulosa Hechtel, 1965. They are both yellow, and share oxeas in a comparable size range [97-460 (582?) vs 40-500 $\mu \mathrm{m}$, sensu DiAZ et al. 1993; 87-349, holotype remeasured]. Important distinctive features are $H$. magniconulosa's tendency to exhibit size categories. DiAz et al. (1993) point to two or three size categories, but we failed to find them in the holotype. There is a length distribution peak at ca. $130 \mu \mathrm{m}$ and another at ca. $300 \mu \mathrm{m}$, but intermediary sizes are plentiful. Additionally, the width of the oxeas measured in the new species $(2.4-8.6-12.5 \mu \mathrm{m})$ is nearly double that of the holotype of $H$. magniconulosa (1.2-4.7-8.4 $\mu \mathrm{m})$ as remeasured here. HECHTEL (1965) considered a distinctive feature of the latter species its darkening in spirit, which is not paralleled by $H$. sulfurea $\mathbf{s p .} \mathbf{n}$.

Halichondria cristata Sarà, 1978 and H. prostrata Thiele, 1905 were both described as yellowish (yellowish-white and light-yellow, respectively), thus approaching $H$. sulfurea $\mathbf{s p}$. $\mathbf{n}$. in this respect. They differ nevertheless in that their smaller oxeas are in the 250-300 $\mu \mathrm{m}$ range, while the new species has common oxeas 
approaching $100 \mu \mathrm{m}$. Additional evidence for the new species' recognition as such stems from the very low similarity of the faunas in both Paulista/Brazilian and Patagonian/Magallanic biogeographic provinces (e.g. PALACIO 1982).

\section{Halichondria tenebrica sp. $\mathbf{n}$.}

Figs 4, 8, 10h-i, 13a-b, 15; Tab. II

Holotype. MNRJ 521, Rocky-coast between Praia do Cabelo Gordo and Ponta do Jarobá, Canal de São Sebastião, São Sebastião, SP, 0.5-1 m, E. Hajdu leg., 16/VI/1997.

Paratype. MNRJ 1316, Ponta do Jarobá, Canal de São Sebastião, São Sebastião, SP, 2 m, E. Hajdu \& Colls leg., 21/XII/1997.

Diagnosis. H. tenebrica $\mathbf{s p .} \mathbf{n}$. is the only Tropical Western Atlantic species of Halichondria with dark-greyish-green live colour, and one size category of oxeas with mean length around $350 \mu \mathrm{m}$, common smaller spicules (ca. $120 \mu \mathrm{m}$ ), and larger spicules beyond $600 \mu \mathrm{m}$.

Description. Thickly encrusting, compressible, with an irregular microhispid surface. Bumps and volcaniform projections occur. A clear subectosomal network was visible on the holotype alive. The holotype is $35 \times 21 \times 14 \mathrm{~mm}$ (length, width, thickness, Figs 4, 8). Live colour is dark-greyish-green or purple, turning greyishpurple in spirit.

Skeleton. The ectosome is made up of a dense tangential reticulation of multispicular tracts of oxeas $(30-140 \mu \mathrm{m})$. Paucispicular, seemingly secondary tracts are seen here and there. There are large pore areas among the tracts (e.g. $300 \mu \mathrm{m}$ across), with up to 30 pores (20-60 $\mu \mathrm{m}$ across) grouped. Spicules strewn in confusion vary widely in abundance from area to area (Fig. 13a). The choanosomal skeleton is densely reticulated by multispicular ascending tracts $(48-223 \mu \mathrm{m})$. Tracts diverge a bit when approaching the surface (Fig. 13b).

Spicules (Figs 10h-i, 15; Tab. II). Oxeas smooth, nearly straight, fusiform, tapering gradually to very sharp endings. Dimensions: $116-708 \mu \mathrm{m}$ in length and 4.8-17.5 $\mu \mathrm{m}$ thick.

Ecology. Both specimens were collected at shallow-waters, at very low energy habitats.

Etymology. The species is named after its dark colour (tenebrosus, tenebricus $=$ latin for dark)

Remarks. Halichondria tenebrica sp. n. approaches $H$. cebimarensis sp. n., described above, and $H$. corrugata. Oxeas smaller than $200 \mu \mathrm{m}$ abound, thus making $H$. tenebrica sp. n. even closer to $H$. corrugata in this respect, than $H$. cebimarensis sp. n. Distinguishing features are the grooved oscular chimneys, light greenishbrown or pink color, and the thinner and more abruptly sharpened oxeas of $H$. corrugata. Besides, the size frequency distribution of oxeas has a marked peak at ca. $500 \mu \mathrm{m}$ (holotype remeasured, Fig. 15), not mirrored by H. tenebrica sp. n., where peaks are nearly indistinguishable (holotype), or near the smaller spicules (ca. $150 \mu \mathrm{m}$, paratype). We believe the distinctive features just quoted, coupled to 
both species seemingly allopatric distribution, confirm their status as two valid species. H. tenebrica $\mathbf{s p}$. n. differs from $H$. cebimarensis $\mathbf{s p .} \mathbf{n}$. by its much darker live-colour, darker colour in spirit, abundance of oxeas smaller than $200 \mu \mathrm{m}$, and a much denser and conspicuous reticulation of tracts of megascleres.

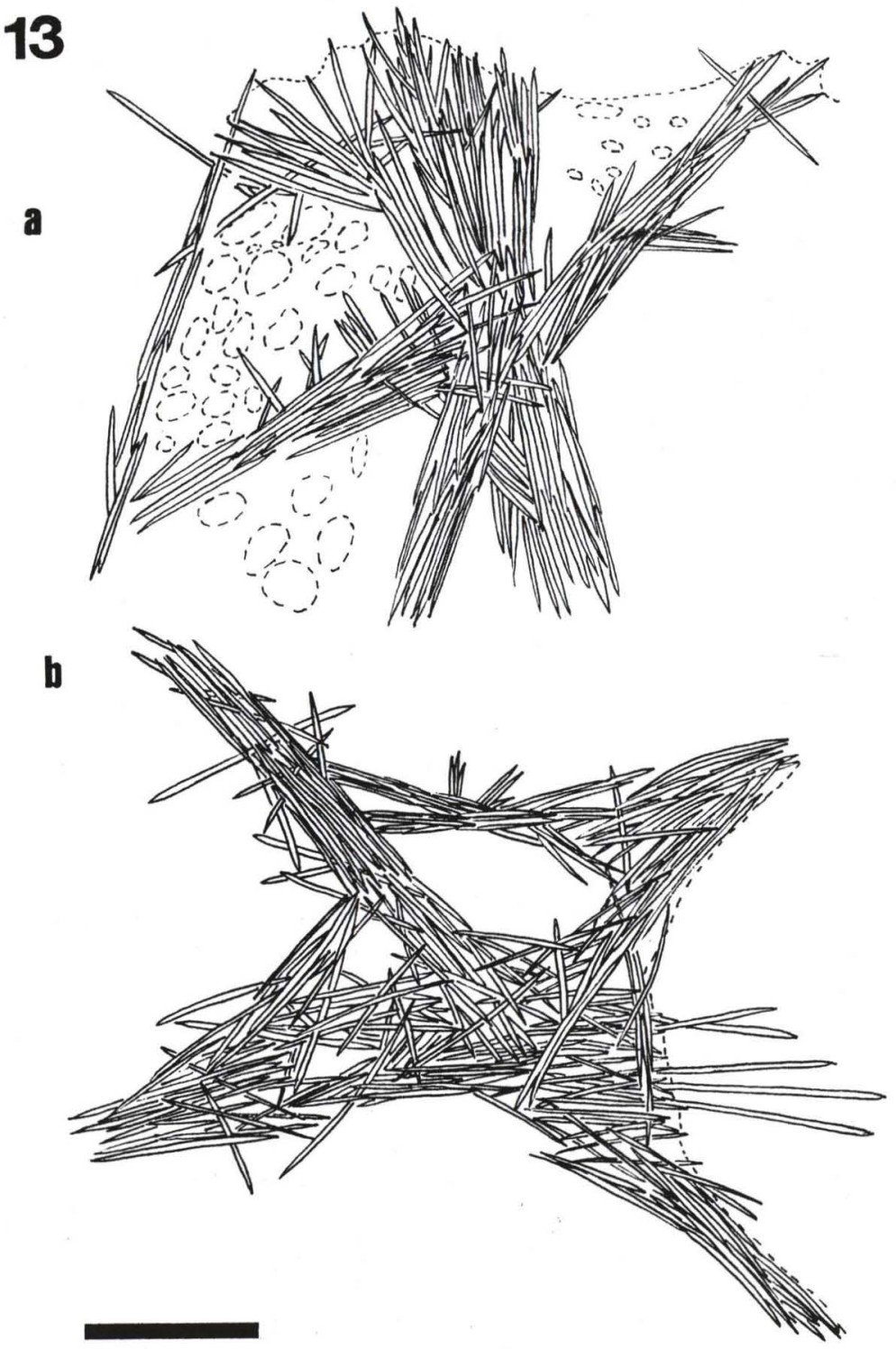

Fig. 13. Halichondria tenebrica sp. n. (a) Ectosomal skeleton, pores are indicated as dashed rounded areas; (b) choanosomal skeleton. Scale bar $=200 \mu \mathrm{m}$. 

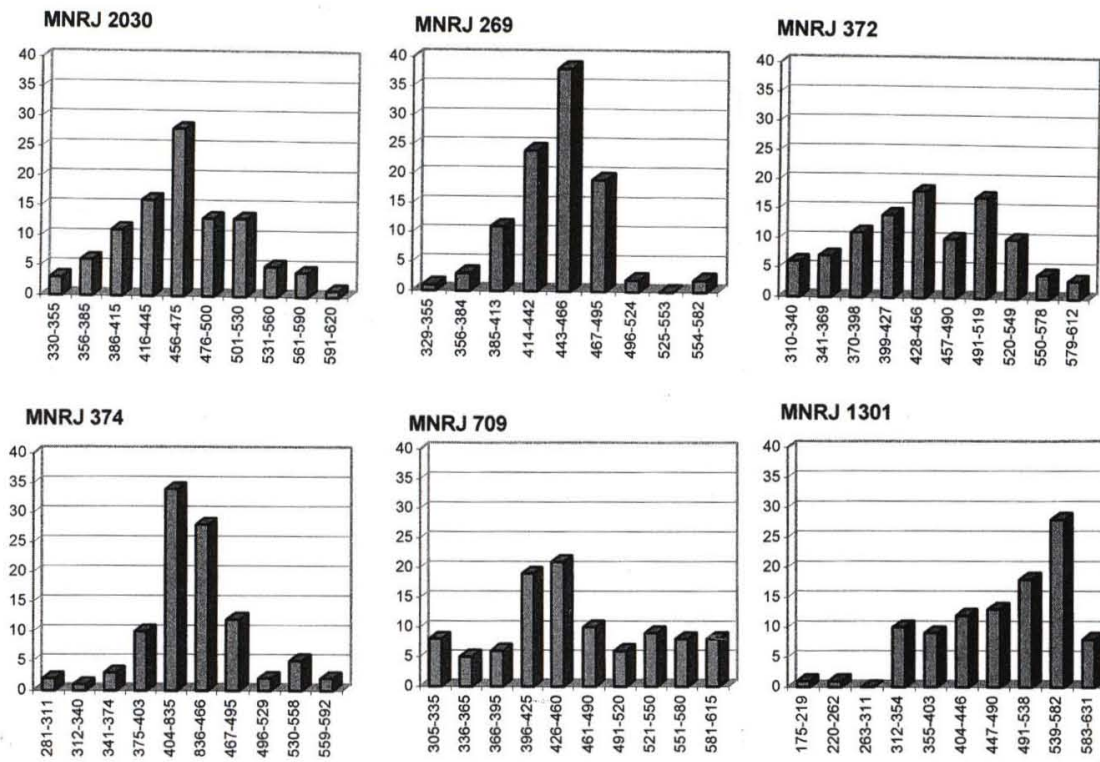

\section{MNRJ 1301}
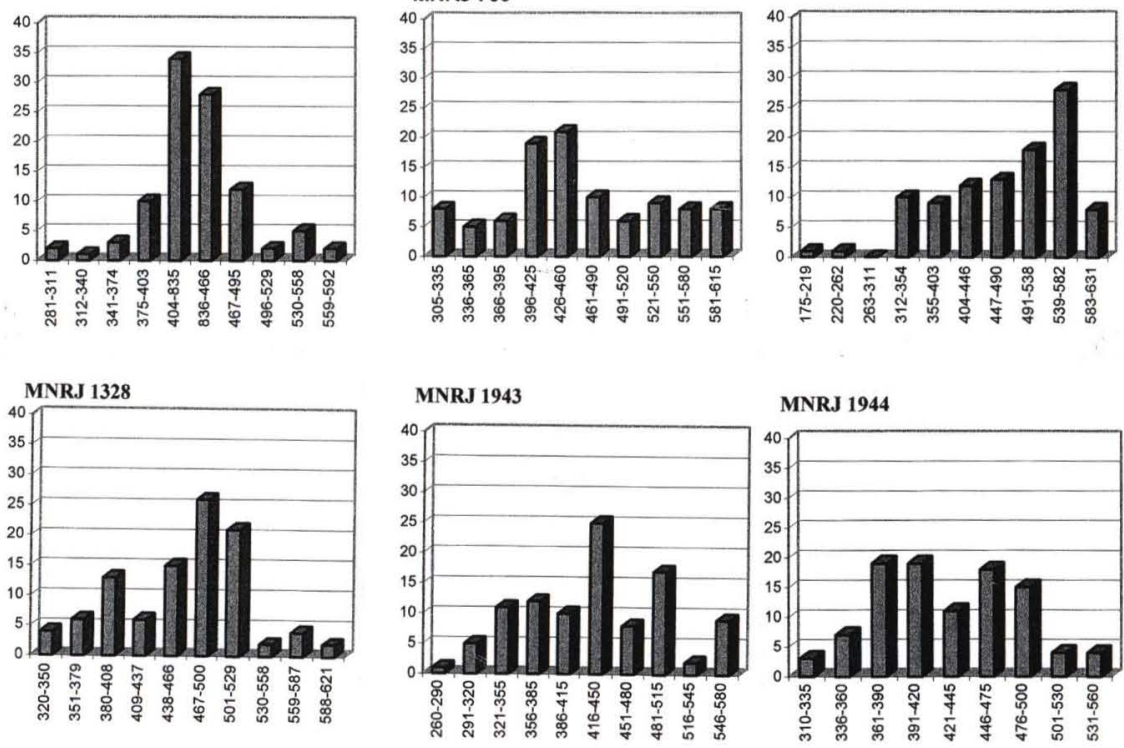

Fig. 14. Distribution frequency of the size-classes of the oxeas of Halichondria cebimarensis sp. n. holotype (MNRJ 2030) and paratypes (MNRJ 269, 372, 374, 709, 1301, 1328, 1943, 1944).

\section{DISCUSSION}

In the context of this article, H. panicea (Pallas, 1766) has been circumscribed to those populations occurring in the Boreal Eastern Atlantic and Mediterranean sea, and perhaps in the Boreal Western Atlantic, and both sides of the Boreal Pacific. VETHAAK et al. (1982), studying a population from the Oosterschelde (Dutch Delta) characterised this species as being of orange-yellow (with or without shades of green) colour, with oxeas in the $190-482 / 2.4-13.6 \mu \mathrm{m}$ range (length/ thickness). These authors considered the oxeas to be classed in slightly smaller ectosomal ones $(190-282.2-475 / 2.4-6.4-13.3 \mu \mathrm{m})$ and correspondingly larger choanosomal ones (171-318.8-482/2.8-7.5-13.6 $\mu \mathrm{m})$, thus corroborating earlier findings by HARTMAN (1958). VETHAAK et al. (1982) conducted a thorough comparison of specimens and 

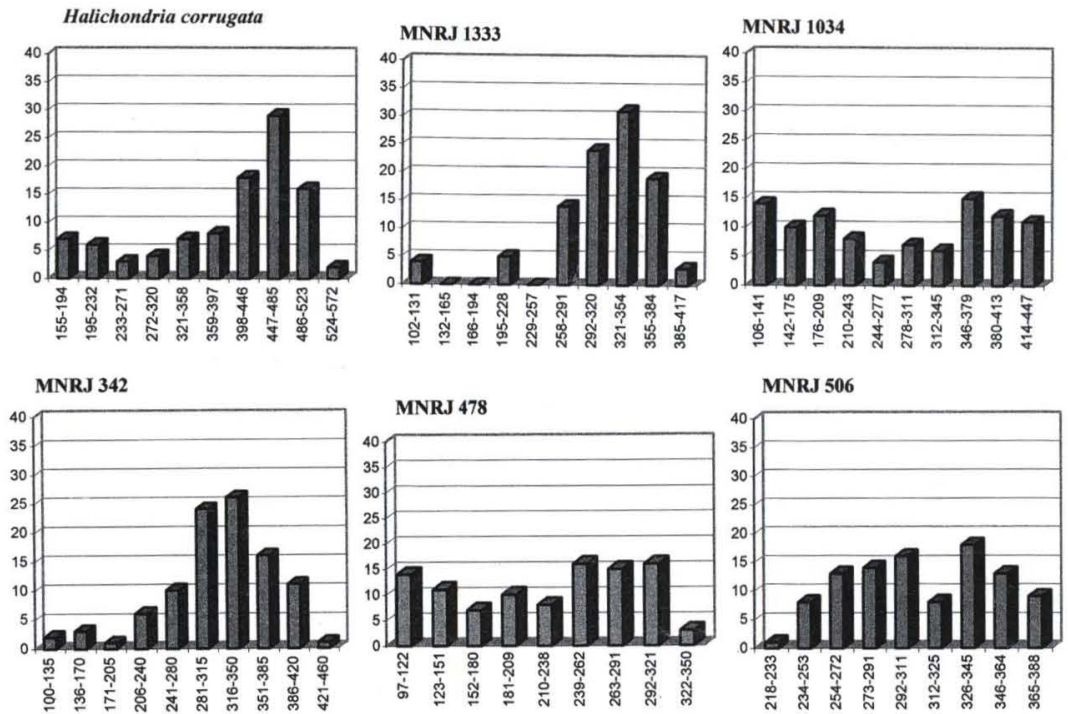

Halichondria magniconulosa
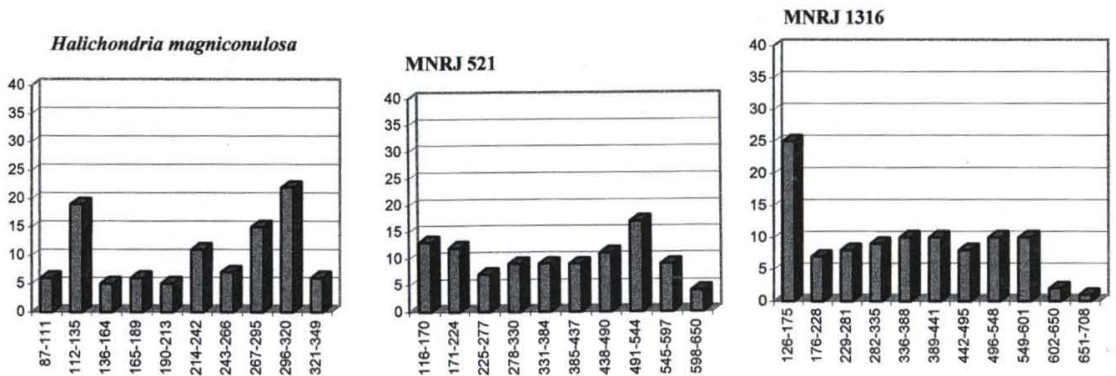

Fig. 15. Halichondria corrugata holotype (USNM 23566); Halichondria migottea sp. n. holotype (MNRJ 1333). Halichondria sulfurea sp. $\mathrm{n}$. holotype (MNRJ 1034) and paratypes (MNRJ 342, 478, 506). Halichondria magniconulosa holotype (YPM 5039); Halichondria tenebrica sp. n. holotype (MNRJ 521) and paratype (MNRJ 1316).

literature records of the species for various parts of the world, and after discarding those records or specimens which appeared too different from European records, still found slightly smaller oxeas in specimens from the Northwestern Atlantic (HARTMAN $1958-127 \mu \mathrm{m}$ ), and from the Northeastern Atlantic too (VETHAAK et al. $1982-124 \mu \mathrm{m}$, Ireland). Slightly larger oxeas occurred only in New Zealand specimens (BERGQUIST 1970 - $490 \mu \mathrm{m}$; VETHAAK et al. $1982-523 \mu \mathrm{m}$ ).

SCHÖNBERG \& BARTHEL (1997) found a mean annual length for the oxeas of $H$. panicea in the Western Baltic Sea at $276.8 \mu \mathrm{m}$, with overall minima and maxima over their sampling period, 76 and $437 \mu \mathrm{m}$, respectively. These authors 
observed temporal variation in mean spicule length and width though. Mean length varied from 227 to $309 \mu \mathrm{m}$, while mean thickness from 6.0 to $9.2 \mu \mathrm{m}$.

The alleged variation allowed by $H$. panicea conducted many authors to assemble an outstandingly large distribution for the species. It is beyond the scope of the present study to go over each of these records verifying their correct status, and it is well possible that some will appear indeed very similar to European records of the species. What is of special concern here are those records of $H$. panicea effected for the Southwestern Atlantic (SARÀ 1978; MURICY et al. 1991).

SARÀ (1978) worked on several specimens of Halichondria from the Tierra del Fuego region (Argentina). Sponges in this area pertain to the Magellan Biogeographic Province and are of antarctic/subantarctic affinities (SARÀ 1978; SARÀ et al. 1992; VAN SOEST 1994). These records are very unlikely to be akin to species collected in the generally warm shallow-waters of the São Sebastião Channel, and relate to the present discussion as outsiders only, in the hope of clarifying Halichondria's diversity and distribution in Atlantic South America.

SARÀ (1978) reported oxeas in the 210-320 $\mu \mathrm{m}$ length range, being 6-10 $\mu \mathrm{m}$ thick. These ranges are far more restricted than those reported for North Atlantic specimens (e.g. HARTMAN 1958; VETHAAK et al. 1982; SCHÖNBERG \& BARTHEL 1997), which poses some doubts on the identification of the Magellan material. VETHAAK et al. (1982) advanced two hypothesis to explain the supposed wide longitudinal and latitudinal distribution of $H$. panicea, viz. 1) dispersion along the whole Western African continent during glacial maxima followed by subsequent long range dispersal to areas such as Northern New Zealand, and 2) recent introduction by man. A third hypothesis is, of course, that these records are not conspecific, no matter how similar they appear morphologically. In our view, the suggestion made by SARA (1978) regarding the likely synonymy of $H$. prostrata to $H$. panicea, is premature. It goes against every likely biogeographic scenario. VETHAAK et al. (1982) did not attach much confidence to their hypotheses either. We suggest thus that SARA's (1978) record of H. panicea for the Tierra del Fuego region is best assigned to $H$. prostrata for the time being, until the conspecificity of both species is made more likely by genetic methods.

MURICY et al. (1991) cited H. panicea for the Tropical Southwestern Atlantic (Arraial do Cabo, Rio de Janeiro State coastline). Here, five specimens of this collection were re-examined, variously identified as $H$. panicea (UFRJPOR 2650, 2663, 3129) and Halichondrida (UFRJPOR 2772, 2972). They appear to be best classed in two separate species. UFRJPOR 2650, 2663, 2772 and 3129, have oxeas ranging from ca. 150 to over $800 \mu \mathrm{m}$ in length, and a category of smaller styles (ca. $150 \mu \mathrm{m}$ long), being thus best classed in Amorphinopsis Carter, 1887. These specimens are likely to be conspecific with additional material collected in the São Sebastião Channel area, found with a similar colour range (yellow to green), and probably belong to a new species, in view of the highly disjunct distribution of other species of the genus (Indo-west Pacific). UFRJPOR 2972 is not a Halichondria either, in view of its ectosomal skeleton which stands between a true palisade and regular brushes, although not very dense. The choanosome is not very dense too, spongin is conspicuous on irregularly ascending tracts, and spicules spread in 
confusion are sparse. This sponge is here hesitatingly assigned to the vicinity of Spongosorites Topsent, 1896 (sensu DiAZ et al. 1993), of which it appears to differ by its soft, easily compressible consistency.

The new species described here, $H$. cebimarensis sp. n., approaches $H$. panicea as circumscribed above. The rationale for considering both as distinct species was furnished at the new species' Remarks' section.

DE LAUBENFELS (1956) identified a Menanetia sp. collected from Ubatuba (in the vicinity of our study area). VAN SOEST et al. (1990) considered Menanetia to be a junior synonym of Halichondria, and DE LAUBENFELS' (1956) record is thus treated as Halichondria sp. We had the opportunity to re-examine de Laubenfels' collection of microscopic preparations (NMNH), but none was identified as Menanetia sp. Several microscopic slides were unidentified, but among these we found five (labels: 55022, 55026, 55044, 55050, 55053), all from Ubatuba, possessing a spicule complement of oxeas of variable sizes only, which are best assigned to Halichondria sp. We suspect these could have been made from de Laubenfels' Menanetia sp. Their oxeas measure: 55022 - 110-305.0520/2.5-15 $\mu \mathrm{m}, 55026$-120-378.5-550/1.3-15 $\mu \mathrm{m}, 55044$ - 120-435.5-720/2.5$23 \mu \mathrm{m}, 55050-130-230.5-480 / 2.5-10 \mu \mathrm{m}, 55053$ - 100-275.0-550/2.5-15 $\mu \mathrm{m}$. All the specimens fit best with the newly described $H$. sulfurea $\mathbf{s p .}$., but for specimen 55044, which approaches $H$. cebimarensis $\mathbf{s p}$. $\mathbf{n}$. It seems thus that de Laubenfels was dealing with two species instead, but we do not feel confident in proposing formal identifications for these specimens. Their life colour is an important missing character.

JOHNSON's (1971) Halichondria sp. (no specimen studied here) was described with oxeas in three size categories, viz. $325 / 8 \mu \mathrm{m}, 625 / 13 \mu \mathrm{m}$ and $713-875 / 25$ $\mu \mathrm{m}$. It appears distinct from any other Tropical Western Atlantic species, and is likely to be new. The specimen has to be re-examined in order to allow a formal decision on its status, and is provisionally kept under Halichondria sp.

HECHTEL's (1983) Halichondria braziliensis is a junior synonym of Topsentia ophiraphidites (De Laubenfels, 1934) according to DIAZ et al. (1993), who re-examined the type specimen, and has accordingly been kept away from any further considerations here.

Halichondria lutea Alcolado, 1984 as found in Brazil (LERNER 1996) is not conspecific to the type material, because it has desmas, and is best assigned to Petromica (MURICY et al. 2001).

MURICY \& MORAES (1998) listed H. magniconulosa for Brazil's Northeastern coastline (Tamandaré, Pernambuco state). Their material (UFRJPOR 4021) was re-examined, and appears correctly identified. It has oxeas ranging from 110 to $520 \mu \mathrm{m}$ which appear to pertain to more than one size category. Smaller spicules are very common. Its live-colour was not noted, and the specimen is considerably macerated. There is another specimen from the same locality, UFRJPOR 4041, live-colour reddish-orange, which has oxeas ranging from 70 to $830 \mu \mathrm{m}$, with larger spicules very common. This specimen is probably of another species, yet undescribed in the Brazilan coast. It is better referred to as Halichondria sp. 
The updated list of Brazilian Halichondria is thus $H$. cebimarensis sp. $\mathbf{n} ., H$. magniconulosa Hechtel, 1965, H. migottea sp. n., Halichondria spp. (= Menanetia sp. sensu DE LAUBENFELS 1956; = Halichondria sp. sensu JOHNSON 1971; = Halichondria sp., UFRJPOR 4041), H. sulfurea sp. n. and H. tenebrica sp. n.

\title{
Identification key for the Brazilian Halichondria
}

Observation. It is recommended that users of the key obtain measures for the length of at least 50-100 oxeas and study their size-frequency distribution prior to starting the identification process.

1. Mean length of the oxeas larger than $400 \mu \mathrm{m}$, live sponges of a turquoise colour H. cebimarensis $\mathbf{s p} \mathbf{n}$.

-. Mean length of the oxeas smaller than $400 \mu \mathrm{m} \ldots \ldots \ldots \ldots \ldots \ldots \ldots 2$

2. Oxeas can be larger than $600 \mu \mathrm{m}$, live sponges of a dark-grayish-green colour.

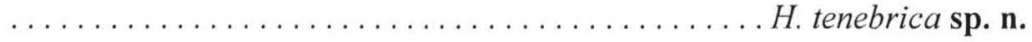

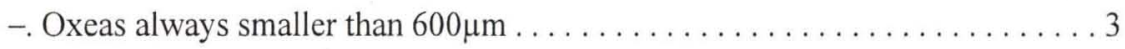

3. Oxeas in three clear-cut size categories (means near 100, 200 and $300 \mu \mathrm{m}$ ), live-colour grayish-brown .................. migottea $\mathbf{s p .} \mathbf{n}$.

-. Oxeas not so clearly ascribed to more than one varied category ranging from ca.

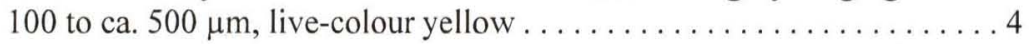

4. Sponges turning to a dark colour when preserved, mean oxea thickness around

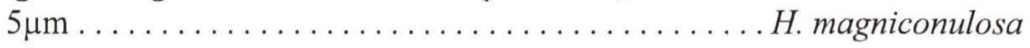

-. Sponges do not turn into darker colours when preserved, mean oxea thickness

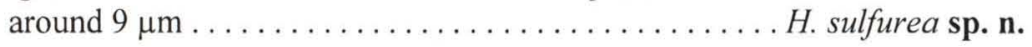

\begin{abstract}
ACKNOWLEDGEMENTS. The authors are thankful to E. Laso-Wasem (YPM), P. Greenhall and K. Rützler (USNM), and C.B. Lerner and B. Mothes (MCNZ), for the loan of comparative material. R.G.S. Berlinck (USP); E. Costa, R. Fernandes and G. Muricy (MNRJ); M.R. Custódio (CEBIMar/USP); M.C. Guerrazzi (UESC) and L.H. Lima (UNICAMP) are thanked for help in the collecting trips. J.C. Freitas (CEBIMar/USP) is thanked for the provision of laboratory facilities and assignment of technical support during the field trips. A.E. Migotto (CEBIMar/USP) is thanked for the donation of the specimen made holotype of $H$. migottea sp. $\mathbf{n}$. Grants and/or fellowships by CNPq, FAPERJ, FAPESP and FUJB (all from Brazil) are greatly acknowledged.
\end{abstract}

\section{REFERENCES}

Bergquist, P.R. 1970. The Marine Fauna of New Zealand: Porifera, Demospongiae. Part 2. (Axinellida and Halichondrida). New Zealand Oceanogr. Inst. Memoir 51: 1-88.

de Laubenfels, M.W. 1956. Preliminary dicussion of the sponges of Brazil. Bol. Inst. Oceanogr. São Paulo (1): 1-4.

DiAZ, M.C.; S.A. POMPONI \& R.W.M. van SOEST. 1993. A systematic revison of the central West Atlantic Halichondrida (Demospongiae, Porifera). Part III: Description of valid species. Sci. Mar. 57 (4): 283-306. 
HaRTMAn, W.D. 1958. Natural History of the Marine Sponges of Southern New England. Bull. Peabody Mus. Nat. Hist. 12: I-XI, 1-155

HeChTEl, G.J. 1965. A systematic study of the Demospongiae of Port Royal, Jamaica. Bull. Peabody Mus. Nat. Hist. 20: 1-94.

1983. New species of marine Demospongiae from Brazil. Iheringia, Sér. Zool. 63: 59-89. HOOPER, J.N.A. 1997. Guide to sponge collection and identification. Brisbane, Qld. Museum, 143p. Jolinson, M.F. 1971. Some marine sponges of northeast Brazil. Arq. Ciênc. Mar. 11 (2): 103-116.

LeRner, C. 1996. Esponjas da Ilha da Galé, Reserva Marinha Biológica do Arvoredo, Santa Catarina, Brasil (Porifera; Demospongiae). Biociências, Porto Alegre, 2 (4): 101-129.

MOTHES-DE-MORAES, B. 1985. Manual de técnicas para a preparação de coleções zoológicas. 2. Esponjas Marinhas. São Paulo, Sociedade Brasileira de Zoologia, CNPq, 3p.

Munro, M.H.G.; J.W. Blunt; R.J. Lake; M. Litaudon; C.N. Battershill \& M.J. Page. 1994. From seabed to sickbed: What are the prospects?,p. 473-484. In: R.W.M. vaN SOEST; T.M.G. VAN KEMPEN \& J.C. Braekman (Eds). Sponges in Time and Space: Biology, Chemistry, Paleontology. Balkema, Rotterdam \& Brookfield, XVIII $+515 p$.

Muricy, G.; E. Hajdu; M. Custodio; M. Klatau; C. Russo \& S. Peixinho. 1991. Sponge distribution at Arraial do Cabo, SE Brazil, p. 1-14. In: O.T. Magoon; H. Converse; V. TippIE; L.T. Tobin \& D. Clark (Eds). Proc. II Symp. Coast. Ocean Manag., p. 1183-1195, ASCE Publ. 2.

Muricy, G.; E. Hajdu; J.V. Minervino; A.V. Madeira \& S. Peixinho. 2001. Systematic revision of the genus Petromica Topsent (Demospongiae: Halichondrida), with a new species from the Southwestern Atlantic. Hydrobiologia 443: 103-128.

Muricy, G. \& F.C. Moraes. 1998. Marine sponges of Pernambuco State, NE Brazil. Rev. Brasil. Oceanogr. 46 (2): 213-217.

PalACiO, F.J. 1982. Revisión zoogeográfica marina del sur del Brasil. Bol. Inst. oceanogr., São Paulo, 31 (1): 69-92.

SARÀ, M. 1978. Demospongie di acque superficiali della Terra del Fuoco (Spedizione AMF Mares-GRSTS e SAI). Bol. Mus. Ist. Biol. Univ. Genova 46: 7-117.

SarÀ, M.; A. Balduzzi; M. Barbieri; G. Bavestrello \& B. Burlando. 1992. Biogeographic traits and checklist of Antarctic demosponges. Polar Biol. 12: 559-585.

SCHÖNBERG, C.H.L. \& D. BARTHEL. 1997. Inorganic skeleton of the demosponge Halichondria panicea. Seasonality in spicule production in the Baltic Sea. Mar. Biol. 130: 133-140.

van SOEST, R.W.M. 1994. Demosponge distribution patterns, p. 213-223p. In: R.W.M. VAN SOEST; T.M.G. van Kempen \& J.C. BRAeKman (Eds). Sponges in Time and Space: Biology, Chemistry, Paleontology. Balkema, Rotterdam \& Brookfield, XVIII+515p.

VAN SoEst, R.W.M.; M.C. Diaz \& S.A. PomPoNI. 1990. Phylogenetic classification of the Halichondrids (Porifera, Demospongiae). Beaufortia 40 (2): 15-62.

VethaAk, A.D.; R.J.A CRONIE \& R.W.M VAn Soest. 1982. Ecology and distribution of two sympatric, closely related sponge species, Halichondria panicea (Pallas, 1976) and H. bowerbanki Burton, 1930 (Porifera, Demospongiae), with remarks on their speciation. Bijdr. Dierk. 52: 82-102.

Recebido em 15.VI.2000; aceito em 22.VI.2001. 